\title{
Amycolatopsis samaneae sp. nov., isolated from roots of Samanea saman (Jacq.) Merr.
}

\author{
Kannika Duangmal, ${ }^{1,2}$ Ratchanee Mingma, ${ }^{1,2}$ Wasu Pathom-aree, ${ }^{3}$ \\ Arinthip Thamchaipenet, ${ }^{2,4}$ Yuki Inahashi, ${ }^{5}$ Atsuko Matsumoto ${ }^{6}$ \\ and Yoko Takahashi ${ }^{5,6}$
}

Correspondence

Kannika Duangmal

fscikkd@ku.ac.th

kannikaduangmal@hotmail.com

\author{
${ }^{1}$ Department of Microbiology, Faculty of Science, Kasetsart University, Chatuchak, Bangkok 10900, \\ Thailand \\ ${ }^{2}$ Center for Advanced Studies in Tropical Natural Resources, National Research University- \\ Kasetsart University (CASTNAR, NRU-KU), Chatuchak, Bangkok 10900, Thailand \\ ${ }^{3}$ Department of Biology, Faculty of Science, Chiang Mai University, Chiang Mai 50200, Thailand \\ ${ }^{4}$ Department of Genetics, Faculty of Science, Kasetsart University, Chatuchak, Bangkok 10900, \\ Thailand \\ ${ }^{5}$ Graduate School of Infection Control Sciences, Kitasato University, 5-9-1 Shirokane, Minato-ku, \\ Tokyo 108-8641, Japan \\ ${ }^{6}$ Kitasato Institute for Life Sciences, Kitasato University, 5-9-1 Shirokane, Minato-ku, Tokyo \\ 108-8641, Japan
}

A novel actinomycete, designated strain $\mathrm{RM}^{2} 87^{\top}$, was isolated from surface-sterilized roots of Samanea saman (Jacq.) Merr., collected from Bangkok, Thailand. The status of the novel strain was determined using a polyphasic taxonomic approach. Phylogenetic analyses based on 16S rRNA gene sequences showed that the organism formed a distinct phyletic line within the radiation of the genus Amycolatopsis. The $16 \mathrm{~S}$ rRNA gene sequence similarity indicated that strain $\mathrm{RM}^{2} 87^{\top}$ was most closely related to Amycolatopsis mediterranei IMSNU $20056^{\top}$ (97.4\%), A. rifamycinica DSM $46095^{\top}$ (97.2\%), A. kentuckyensis NRRL B-24129 ${ }^{\top}$ (97.2\%), A. pretoriensis DSM $44654^{\top}$ (97\%) and $A$. australiensis DSM $44671^{\top}(97 \%)$. The novel organism was found to have chemical properties typical of members of the genus Amycolatopsis such as meso-diaminopimelic acid as the dignostic diamino acid in the cell-wall peptidoglycan and arabinose and galactose as the diagnostic sugars. The major menaquinone was $M K-9\left(\mathrm{H}_{4}\right)$. The major fatty acids were iso- $\mathrm{C}_{16: 0}$ iso- $\mathrm{C}_{15: 0}$, iso $2-\mathrm{OH}-\mathrm{C}_{16: 0}$ and iso- $\mathrm{C}_{17: 0}$. The DNA G+C content was $71.7 \mathrm{~mol} \%$. Phenotypic data clearly distinguished the novel isolate from its closest relatives. The combined genotypic and phenotypic data indicated that strain $\mathrm{RM}^{287^{\top}}$ represented a novel species of the genus Amycolatopsis. The proposed name for this organism is Amycolatopsis samaneae sp. nov., with the type strain RM287 ${ }^{\top}\left(=\operatorname{TISTR}_{1919^{\top}}=\mathrm{BCC} 35842^{\top}=\operatorname{NBRC} 106095^{\top}\right)$.
The genus Amycolatopsis comprises a large group of commercially and medically important actinomycetes. The genus was proposed by Lechevalier et al. (1986) and its description has been emended recently by Lee (2009). Many novel species of this genus have been isolated from diverse environments such as clinical material (Labeda et al., 2003; Huang et al., 2004), natural caves (Lee, 2006), ocean sediment (Bian et al., 2009), soil (Tan et al., 2006; Tseng et al., 2006; Lee, 2009) and vegetable matter

Abbreviation: ISP, International Streptomyces Project.

The GenBank/EMBL/DDBJ accession number for the 16S rRNA gene sequence of strain RM287 ${ }^{\top}$ is GQ381310.
(Goodfellow et al., 2001). The present study was designed to determine the status of Amycolatopsis strain RM $287^{\mathrm{T}}$, isolated from surface-sterilized plant roots, using a polyphasic taxonomic approach. It was evident from the data obtained that this organism represents a novel species of the genus Amycolatopsis.

As part of our discovery programme for endophytic actinomycetes, strain $\mathrm{RM} 287^{\mathrm{T}}$ was isolated from a leguminous plant using starch casein agar (Küster \& Williams, 1964) supplemented with ketokonazole $\left(100 \mu \mathrm{g} \mathrm{ml}^{-1}\right)$ and nalidixic acid $\left(25 \mu \mathrm{g} \mathrm{ml}^{-1}\right)$. Plates that had been inoculated with surface-sterilized crushed root suspensions of Samanea saman were incubated at $28{ }^{\circ} \mathrm{C}$ for 14 days. The 
organism was purified and maintained on glucose yeast extract agar slants [GYE agar; containing $1.0 \%$ glucose $(\mathrm{w} / \mathrm{v}), 1 \%$ yeast extract $(\mathrm{w} / \mathrm{v})$ and $1.5 \%$ agar $(\mathrm{w} / \mathrm{v})]$ at room temperature as the working culture. The pure culture was also preserved as mixtures of fragmented hyphae and spores in $20 \%$ glycerol at $-20{ }^{\circ} \mathrm{C}$ or as lyophilized cells for long-term storage. Biomass for chemotaxonomic analysis was obtained by growing the novel strain in shake flasks of GYE broth for 3 days at $28{ }^{\circ} \mathrm{C}$. The cells were harvested by centrifugation. The resultant cells were washed three times with distilled water and freeze-dried.

The phylogenetic position of the new isolate was determined by $16 \mathrm{~S}$ rRNA gene sequence analysis. Genomic DNA was extracted and purified following the method of Kieser et al. (2000). The 16S rRNA gene was amplified as described by Duangmal et al. (2005). The PCR products were sequenced (Macrogen) using universal primers (Lane, 1991). The almost complete 16S rRNA gene sequence (1417 bp) was aligned with the corresponding sequences of representatives of the genus Amycolatopsis, retrieved from the GenBank database, using the CLUSTAL_X (Thompson et al., 1997) and PHYDIT programs (http://plaza.snu.ac.kr/ $\sim$ jchun/phydit/). Phylogenetic trees were inferred by the least-squares (Fitch \& Margoliash, 1967), maximumparsimony (Fitch, 1971) and neighbour-joining (Saitou \& Nei, 1987) tree-making algorithms from the PHYLIP suite of programs (Felsenstein, 1993). The resultant tree topologies were evaluated using bootstrap analyses (Felsenstein, 1985) based on 1000 resampled datasets of the SЕQBOOT and CONSENSE options from the PHYLIP package. The resultant phylogenetic trees were viewed by using the TreeView program (Page, 1996).

It was evident from the $16 \mathrm{~S}$ rRNA gene phylogenetic tree that strain $\mathrm{RM} 287^{\mathrm{T}}$ formed a distinct phyletic line within members of the genus Amycolatopsis (Fig. 1). The $16 \mathrm{~S}$ rRNA gene sequence similarities between strain RM $287^{\mathrm{T}}$ and its nearest neighbour, Amycolatopsis mediterranei IMSNU $20056^{\mathrm{T}}$ showed that the two organisms shared a $16 \mathrm{~S}$ rRNA gene sequence similarity of $97.4 \%$, a value that corresponded to 36 differences at 1412 locations. In addition, the novel isolate showed relatively low $16 \mathrm{~S}$ rRNA gene sequence similarities with Amycolatopsis rifamycinica DSM $46095^{\mathrm{T}}(97.2 \%), \quad$ A. kentuckyensis NRRL B-24129 $9^{\mathrm{T}}(97.2 \%)$, A. pretoriensis DSM $44654^{\mathrm{T}}$ $(97 \%)$ and A. australiensis DSM $44671^{\mathrm{T}}(97 \%)$. However, it was clear that strain $\mathrm{RM} 287^{\mathrm{T}}$ represented a novel subline within the genus Amycolatopsis as its position in the tree was well separated from these nearest phylogenetic neighbours and all other members of the genus (Fig. 1). DNA-DNA relatedness studies were not performed between the new isolate and its closest phylogenetic neighbours as it has been shown that members of the genus Amycolatopsis that share much higher 16S rRNA gene sequence similarities had DNA-DNA relatedness values well below the $70 \%$ cut-off point (Wayne et al., 1987) for strains that belonged to the same genomic species (Labeda et al., 2003; Tan et al., 2007).
The cultural characteristics of strain $\mathrm{RM} 287^{\mathrm{T}}$ were examined on ISP 2, 4, 5, 6 and 7 media (International Streptomyces Project; Shirling \& Gottlieb, 1966) and GYE agar. The colour of the mycelium and soluble pigment were determined by comparing them with the colour chips from the Colour Harmony Manual (Jacobson et al., 1958). Morphological characteristics were observed by light and scanning electron microscopy (JSM $5600 \mathrm{LV}$; JEOL) of 10 day old cultures grown on ISP 3 medium. Acid production from carbohydrates was determined using the media and methods described by Gordon et al. (1974). Enzyme activity profiles were examined using API ZYM (bioMérieux) tests. Urease activity was determined by a colour change on urea agar (Gordon et al., 1974). The temperature range for growth was determined on GYE agar using a temperature gradient incubator (Tokyo Kagaku Sangyo) with low and high temperatures of 5 and $50{ }^{\circ} \mathrm{C}$, respectively. The production of hydrogen sulphide was detected using lead acetate strips. Hydrolysis of casein and gelatin and nitrate reduction were examined using the methods of Gordon \& Mihm (1957). Production of melanoid pigment was according to Shirling \& Gottlieb (1966). NaCl tolerance was studied on ISP 2 medium containing $\mathrm{NaCl}$ at a final concentration of $1-12 \%(\mathrm{w} / \mathrm{v})$ (at intervals of $1 \%$ ).

Standard procedures were used to determine the isomers of diaminopimelic acid (Hasegawa et al., 1983). The acyl type of the cell wall was analysed according to the method of Uchida \& Aida (1984). Whole-cell sugars were determined as described by Becker et al. (1965). Menaquinones were extracted and purified by the method of Collins et al. (1977), and isoprene units were subsequently analysed by LC/MS (JMS-T100LP; JEOL) with a PEGASIL ODS column $(2.0 \varnothing \times 50 \mathrm{~mm})$ using methanol/2-propanol (7:3). Mycolic acids were detected by TLC according to the method of Tomiyasu (1982). Polar lipids were examined by TLC using the method of Minnikin et al. (1977). The G + C content (mol \%) of the DNA was determined by HPLC according to the method of Tamaoka \& Komagata (1984). Analysis of the fatty acids was performed according to the procedures of the Sherlock Microbial Identification System (Microbial ID).

Strain $\mathrm{RM} 287^{\mathrm{T}}$ was a non-motile, aerobic, Gram-positive filamentous actinomycete. Mycelium developed well on ISP 2, 5, 6, 7 media and GYE agar with white aerial mycelium and yellowish brown substrate mycelium after 10 days at $28{ }^{\circ} \mathrm{C}$. Moderate growth occurred on ISP 3 and ISP 4 media. Light yellowish soluble pigments were produced on ISP 2, 5, 6, 7 media and GYE agar, but not on ISP 3 or ISP 4 media. Chains of fragmented rod-shaped elements of aerial mycelium were observed (Fig. 2).

The results from chemical analysis indicated that strain RM $287^{\mathrm{T}}$ had chemotaxonomic markers typical of the genus Amycolatopsis. The strain contained meso-diaminopimelic acid as the diagnostic diamino acid in the cell-wall peptidoglycan and MK-9 $\left(\mathrm{H}_{4}\right)$ as the major menaquinone. Arabinose and galactose were detected as the major 


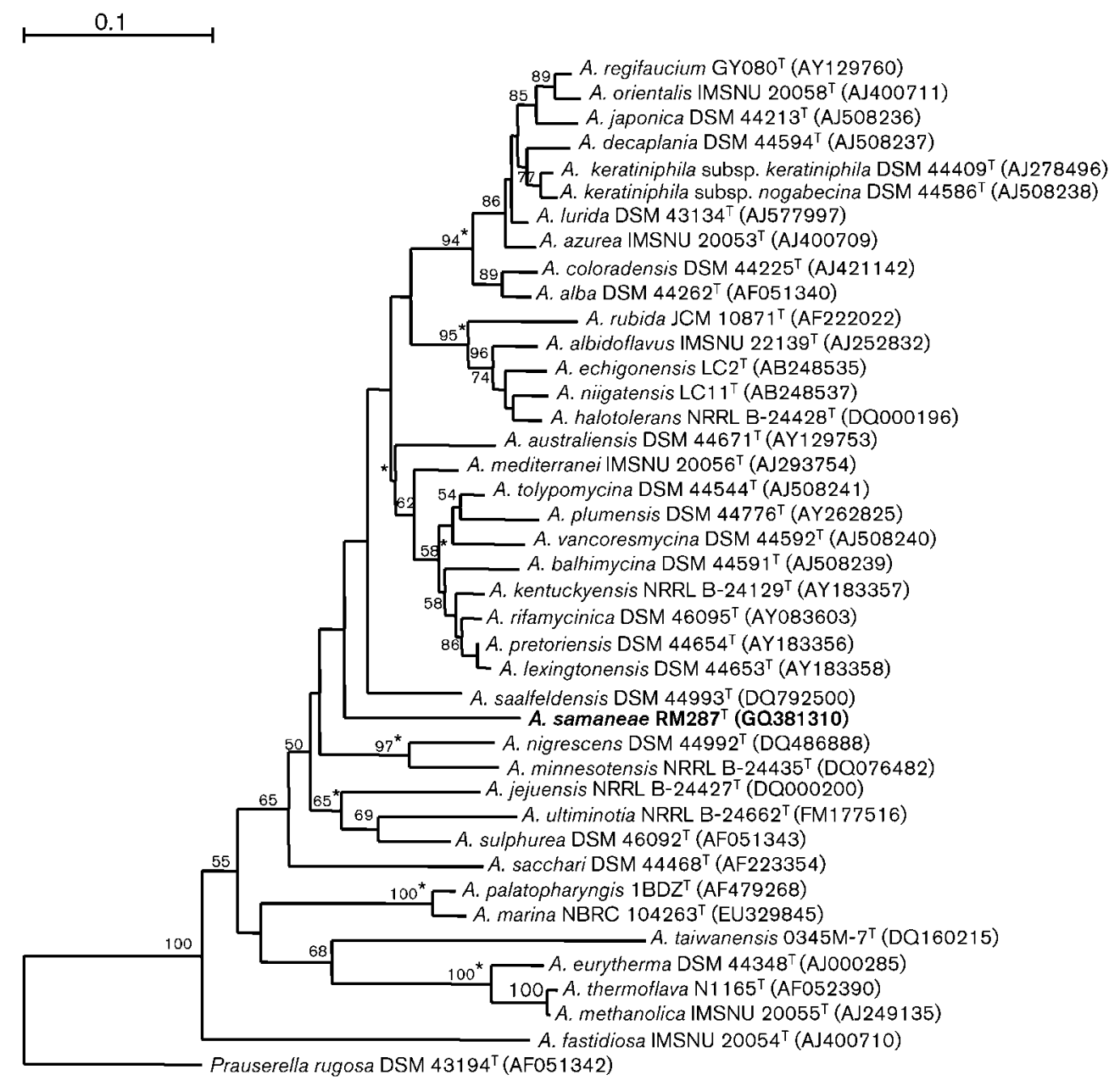

Fig. 1. Neighbour-joining (Saitou \& Nei, 1987) phylogenetic tree based on nearly complete 16S rRNA gene sequences showing the position of strain RM287 ${ }^{\top}$ in the genus Amycolatopsis. Asterisks indicate branches that were also found using the least-squares (Fitch \& Margoliash, 1967) and maximum-parsimony (Fitch, 1971) tree-making algorithms. Numbers at the nodes indicate the percentage bootstrap support from an analysis of 1000 resampled datasets (only values $\geqslant 50 \%$ are shown). Bar, 0.1 substitutions per site.

components of sugars in the whole-cell hydrolysates. Polar lipid analysis showed that the organism contained diphosphatidylglycerol, hydroxy-phosphatidylethanolamine, phosphatidylethanolamine, phosphatidylglycerol, phosphatidylinositol and phosphatidylinositol mannoside. The major fatty acids were iso- $\mathrm{C}_{16: 0}(29.3 \%)$ iso- $\mathrm{C}_{15: 0}$ $(13.9 \%)$, iso $2-\mathrm{OH}-\mathrm{C}_{16: 0}(10.4 \%)$ and iso- $\mathrm{C}_{17: 0}(10.0 \%)$. Fatty acids found in smaller proportions included anteiso$\mathrm{C}_{17: 0}(6.9 \%), \mathrm{C}_{16: 0}(6.2 \%), 2-\mathrm{OH}-\mathrm{C}_{16: 1}(3.7 \%), \mathrm{C}_{18: 0}$ $(2.5 \%)$, anteiso $2-\mathrm{OH}-\mathrm{C}_{17: 0}(2.1 \%)$, anteiso- $\mathrm{C}_{15: 0}(1.5 \%)$ and anteiso $2-\mathrm{OH}-\mathrm{C}_{15: 0}(1.4 \%)$. No mycolic acids were detected. The $\mathrm{G}+\mathrm{C}$ content of the DNA was $71.7 \mathrm{~mol} \%$.

The assignment of strain $\mathrm{RM} 287^{\mathrm{T}}$ to the genus Amycolatopsis was supported by biochemical, morphological and physiological evidence. The novel strain was positive for allantoinase, catalase and urease. The temperature range for growth was $16-40{ }^{\circ} \mathrm{C}$ and good growth was observed at $25-34{ }^{\circ} \mathrm{C}$.

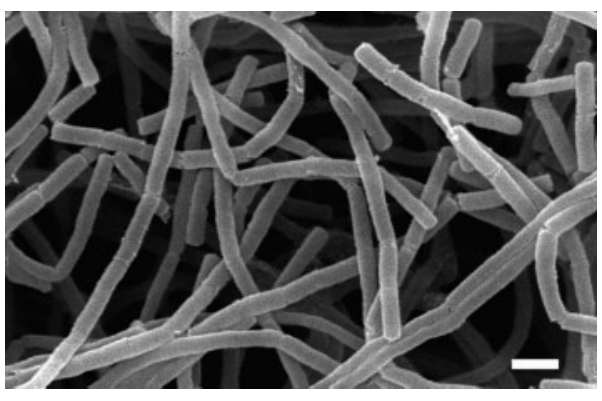

Fig. 2. Scanning electron micrograph of fragmented aerial mycelia of strain RM287 grown on ISP 3 medium for 10 days at $28^{\circ} \mathrm{C}$. Bar, $1 \mu \mathrm{m}$. 
Table 1. Differential characteristics of strain $R M 287^{\top}$ and closely related strains of the genus Amycolatopsis

Strains: 1 , RM287 ${ }^{\mathrm{T}} ; 2$, A. mediterranei $\mathrm{JCM} 4789^{\mathrm{T}} ; 3$, A. rifamycinica JCM $12674^{\mathrm{T}}$; 4, A. kentuckyensis JCM $12670^{\mathrm{T}} ; 5$, A. pretoriensis JCM $12673^{\mathrm{T}} ; 6$, A. australiensis JCM $15587^{\mathrm{T}}$. +, Positive; -, negative.

\begin{tabular}{|c|c|c|c|c|c|c|}
\hline Characteristic & 1 & 2 & 3 & 4 & 5 & 6 \\
\hline \multicolumn{7}{|l|}{ Acid production from: } \\
\hline Adonitol & + & - & - & - & - & - \\
\hline$(+)$-L-Arabinose & - & + & + & + & + & + \\
\hline Maltose & - & + & - & + & + & + \\
\hline Raffinose & - & + & - & + & + & + \\
\hline (-)-D-Rhamnose & - & + & + & + & + & + \\
\hline Sucrose & - & + & + & + & + & + \\
\hline$(+)$-D-Xylose & - & + & + & + & + & + \\
\hline Allantoinase production & + & - & - & + & - & + \\
\hline Decomposition of xanthine & + & - & - & - & + & - \\
\hline Growth at $10 \% \mathrm{NaCl}(\mathrm{w} / \mathrm{v})$ & + & - & - & - & - & - \\
\hline
\end{tabular}

No growth was observed at or above $42{ }^{\circ} \mathrm{C}$. The strain was able to grow at $\mathrm{pH}$ 5.0-11.0. The organism tolerated up to $10 \%(\mathrm{w} / \mathrm{v}) \mathrm{NaCl}$. Melanin pigment was not produced. Strain $\mathrm{RM} 287^{\mathrm{T}}$ could be readily differentiated from its closest relatives $A$. mediterranei $\mathrm{JCM} 4789^{\mathrm{T}}$, A. rifamycinica $\mathrm{JCM}$ $12674^{\mathrm{T}}$, A. kentuckyensis JCM $12670^{\mathrm{T}}$, A. pretoriensis JCM $12673^{\mathrm{T}}$ and A. australiensis JCM $15587^{\mathrm{T}}$ on the basis of physiological properties (Table 1), in particular on the production of allantoinase and decomposition of xanthine which were both positive in the novel strain. These characteristics were negative for $A$. mediterranei and $A$. rifamycinica. No acid was produced from $(+)$-L-arabinose, $(-)$-D-rhamnose, sucrose or $(+)$-D-xylose, properties which were positive for $A$. mediterranei, $A$. rifamycinica, $A$. kentuckyensis, A. pretoriensis and A. australiensis. Moreover, growth at $10 \%(\mathrm{w} / \mathrm{v}) \mathrm{NaCl}$ was observed only for strain $\mathrm{RM} 287^{\mathrm{T}}$.

It is apparent that on the basis of genotypic and phenotypic data, strain $\mathrm{RM} 287^{\mathrm{T}}$ could be distinguished from $A$. mediterranei, A. rifamycinica, A. kentuckeyensis, A. pretoriensis and $A$. australiensis. It is concluded that strain RM $287^{\mathrm{T}}$ represents a novel species of the genus Amycolatopsis, for which the name Amycolatopsis samaneae sp. nov. is proposed.

\section{Description of Amycolatopsis samaneae sp. nov.}

Amycolatopsis samaneae [sa.ma.ne' ae. N.L. n. Samanea the name of a botanical genus; N.L. gen. n. samaneae of Samanea, isolated from root of Samanea saman (Jacq.) Merr.].

Aerobic, Gram-positive, non-acid-alcohol-fast, non-motile and catalase-positive actinomycete. Forms extensively branched vegetative mycelia. Aerial hyphae fragment into squarish rod-shaped elements. The aerial mycelium is white, with yellowish to yellowish brown substrate mycelium and soluble light yellow pigment production on ISP 2, 5, 6 and 7 media and GYE agar. $\mathrm{H}_{2} \mathrm{~S}$ production and the nitrate reduction test are negative. Allantoinase production and urease are positive. Acid is produced from adonitol, (+)-D-cellobiose, fucose, ( - -D-fructose, $(+)$ D-galactose, $(+)$-D-glucose, glycerol, myo-inositol, lactose, $(-)$-D-mannitol, (+)-D-mannose, (-)-D-ribose and $(+)$-D-trehalose. No acid production from $(+)$-L-arabinose, maltose, melibiose, $(-)$-D-rhamnose, raffinose, $(-)$ D-sorbitol, sorbose, sucrose, xylitol or (+)-D-xylose. Aesculin, arbutin, casein, gelatin, hypoxanthine, L-tyrosine and xanthine are degraded. Adenine, cellulose, chitin, guanine and starch are not degraded. The $\mathrm{pH}$ range for growth is $\mathrm{pH}$ 5.0-11.0. Cells can grow in the presence of 0-10\% (w/v) NaCl. Acid phosphatase, alkaline phosphatase, chymotrypsin, cystine aminopeptidase, $\beta$-glucosidase, leucine aminopeptidase, lipase $\mathrm{C} 8$, lipase $\mathrm{C} 14, \alpha$-mannosidase, $N$-acetyl- $\beta$-glucosaminidase and valine aminopeptidase are detected with the API ZYM enzyme assay; tests for esterase C4, $\alpha$-galactosidase, $\beta$-galactosidase, $\alpha$-fucosidase, $\alpha$-glucosidase, $\beta$-glucuronidase, phosphoamidase and trypsin are negative. The diagnostic diamino acid of the cell-wall peptidoglycan is meso-diaminopimelic acid. Whole cell sugars are arabinose and galactose. The glycan moiety of the murein is acetylated. The major menaquinone is MK$9\left(\mathrm{H}_{4}\right)$. Mycolic acids are not detected. The polar lipids are diphosphatidylglycerol, hydroxy-phosphatidylethanolamine, phosphatidylethanolamine, phosphatidylglycerol, phosphatidylinositol and phosphatidylinositol mannoside. The major fatty acids in the cellular fatty acid profile are iso$\mathrm{C}_{16: 0}$, iso- $\mathrm{C}_{15: 0}$, iso $2-\mathrm{OH}-\mathrm{C}_{16: 0}$ and iso- $\mathrm{C}_{17: 0}$.

The type strain, strain RM287 ${ }^{\mathrm{T}}$ (=TISTR $1919^{\mathrm{T}}=\mathrm{BCC}$ $35842^{\mathrm{T}}=\mathrm{NBRC} 106095^{\mathrm{T}}$ ), was isolated from roots of Samanea saman (Jacq.) Merr., collected from Kasetsart University, Bangkok, Thailand. The G+C content of the type strain DNA is $71.7 \mathrm{~mol} \%$.

\section{Acknowledgements}

We would like to thank Professor J. P. Euzéby for his kind advice on naming the species. This study was supported by Kasetsart University Research and Development Institute, Faculty of Science, Kasetsart University and Kitasato University.

\section{References}

Becker, B., Lechevalier, M. P. \& Lechevalier, H. A. (1965). Chemical composition of cell-wall preparations from strains of various formgenera of aerobic actinomycetes. Appl Microbiol 13, 236-243.

Bian, J., Li, Y., Wang, J., Song, F.-H., Liu, M., Dai, H.-O., Ren, B., Gao, H., $\mathrm{Hu}, \mathbf{X}$. \& other authors (2009). Amycolatopsis marina sp. nov., an actinomycete isolated from an ocean sediment. Int J Syst Evol Microbiol 59, 477-481.

Collins, M. D., Pirouz, T., Goodfellow, M. \& Minnikin, D. E. (1977). Distribution of menaquinones in actinomycetes and corynebacteria. $J$ Gen Microbiol 100, 221-230.

Duangmal, K., Ward, A. C. \& Goodfellow, M. (2005). Selective isolation of members of the Streptomyces violaceoruber clade from soil. FEMS Microbiol Lett 245, 321-327. 
Felsenstein, J. (1985). Confidence limits on phylogeny: an appropriate use of the bootstrap. Evolution 39, 783-791.

Felsenstein, J. (1993). PHYLIP (phylogenetic inference package) version 3.5c. Distributed by the author. University of Washington, Seattle, USA.

Fitch, W. M. (1971). Towards defining the course of evolution: minimum change for a specific tree topology. Syst Zool 20, 406-416.

Fitch, W. M. \& Margoliash, E. (1967). Construction of phylogenetic trees. Science 155, 279-284.

Goodfellow, M., Kim, S. B., Minnikin, D. E., Whitehead, D., Zhou, Z. H. \& Mattinson-Rose, A. D. (2001). Amycolatopsis sacchari sp. nov., a moderately thermophilic actinomycete isolated from vegetable matter. Int J Syst Evol Microbiol 51, 187-193.

Gordon, R. E. \& Mihm, J. M. (1957). A comparative study of some strains received as nocardiae. J Bacteriol 73, 15-27.

Gordon, R. E., Barnett, D. A., Handerhan, J. E. \& Pang, C. H.-N. (1974). Nocardia coeliaca, Nocardia autotrophica, and the nocardin strain. Int J Syst Bacteriol 24, 54-63.

Hasegawa, T., Takizawa, M. \& Tanida, S. (1983). A rapid analysis for chemical grouping of aerobic actinomycetes. J Gen Appl Microbiol 29, 319-322.

Huang, Y., Paściak, M., Liu, Z. H., Xie, Q. \& Gamian, A. (2004). Amycolatopsis palatopharyngis sp. nov., a potentially pathogenic actinomycete isolated from a human clinical source. Int J Syst Evol Microbiol 54, 359-363.

Jacobson, E., Grauville, W. C. \& Fogs, C. E. (1958). Color Harmony Manual, 4th edn. Chicago: Container Corporation of America.

Kieser, T., Bibb, M. J., Buttner, M. J., Chater, K. F. \& Hopwood, D. A. (2000). Practical Streptomyces Genetics. Norwich: John Innes Foundation.

Küster, E. \& Williams, S. T. (1964). Selection of media for isolation of streptomycetes. Nature 202, 928-929.

Labeda, D. P., Donahue, J. M., Williams, N. M., Sells, S. F. \& Henton, M. M. (2003). Amycolatopsis kentuckyensis sp. nov., Amycolatopsis lexingtonensis sp. nov. and Amycolatopsis pretoriensis sp. nov., isolated from equine placentas. Int J Syst Evol Microbiol 53, 1601-1605.

Lane, D. J. (1991). 16S/23S rRNA sequencing. In Nucleic Acid Techniques in Bacterial Systematics, pp. 115-148. Edited by E. Stackebrandt \& M. Goodfellow. Chichester: John Wiley \& Sons.

Lechevalier, M. P., Prauser, H., Labeda, D. P. \& Ruan, J.-S. (1986), Two new genera of nocardioform actinomycetes: Amycolata gen. nov. and Amycolatopsis gen. nov. Int J Syst Bacteriol 36, 29-37.
Lee, S. D. (2006). Amycolatopsis jejuensis sp. nov. and Amycolatopsis halotolerans sp. nov., novel actinomycetes isolated from a natural cave. Int J Syst Evol Microbiol 56, 549-553.

Lee, S. D. (2009). Amycolatopsis ultiminotia sp. nov., isolated from rhizosphere soil, and emended description of the genus Amycolatopsis. Int J Syst Evol Microbiol 59, 1401-1404.

Minnikin, D. E., Patel, P. V., Alshamaony, L. \& Goodfellow, M. (1977). Polar lipid composition in the classification of Nocardia and related bacteria. Int J Syst Bacteriol 27, 104-117.

Page, R. D. M. (1996). TreeView: an application to display phylogenetic trees on personal computers. Comput Appl Biosci 12, 357-358.

Saitou, N. \& Nei, M. (1987). The neighbor-joining method: a new method for reconstructing phylogenetic trees. Mol Biol Evol 4, 406425.

Shirling, E. B. \& Gottlieb, D. (1966). Methods for characterization of Streptomyces species. Int J Syst Bacteriol 16, 313-340.

Tamaoka, J. \& Komagata, K. (1984). Determination of DNA base composition by reversed-phase high-performance liquid chromatography. FEMS Microbiol Lett 25, 125-128.

Tan, G. Y. A., Robinson, S., Lacey, E. \& Goodfellow, M. (2006). Amycolatopsis australiensis sp. nov., an actinomycete isolated from arid soils. Int J Syst Evol Microbiol 56, 2297-2301.

Tan, G. Y. A., Robinson, S., Lacey, E., Brown, R., Kim, W. \& Goodfellow, M. (2007). Amycolatopsis regifaucium sp. nov., a novel actinomycete that produces kigamicins. Int J Syst Evol Microbiol 57, 2562-2567.

Thompson, J. D., Gibson, T. J., Plewniak, F., Jeanmougin, F. \& Higgins, D. G. (1997). The CLUSTAL_X windows interface: flexible strategies for multiple sequence alignment aided by quality analysis tools. Nucleic Acids Res 25, 4876-4882.

Tomiyasu, I. (1982). Mycolic acid composition and thermally adaptative changes in Nocardia asteroides. J Bacteriol 151, 828-837.

Tseng, M., Yang, S.-F., Li, W.-J. \& Jiang, C.-L. (2006). Amycolatopsis taiwanensis sp. nov., from soil. Int J Syst Evol Microbiol 56, 1811-1815.

Uchida, K. \& Aida, K. (1984). An improved method for the glycolate test for simple identification of the acyl type of bacterial cell walls. J Gen Appl Microbiol 30, 131-134.

Wayne, L. G., Brenner, D. J., Colwell, R. R., Grimont, P. A. D., Kandler, O., Krichevsky, M. I., Moore, L. H., Moore, W. E. C., Murray, R. G. E. \& other authors (1987). International Committee on Systematic Bacteriology. Report of the ad hoc committee on the reconciliation of approaches to bacterial systematics. Int J Syst Bacteriol 37, 463-464. 